\title{
Studying Chinese Politics: Farewell to Revolution?
}

\section{Citation}

Perry, Elizabeth J. 2007. Studying Chinese politics: Farewell to revolution? China Journal 57:1-22.

\section{Permanent link}

http://nrs.harvard.edu/urn-3:HUL.InstRepos:11595641

\section{Terms of Use}

This article was downloaded from Harvard University's DASH repository, and is made available under the terms and conditions applicable to Other Posted Material, as set forth at http:// nrs.harvard.edu/urn-3:HUL.InstRepos:dash.current.terms-of-use\#LAA

\section{Share Your Story}

The Harvard community has made this article openly available.

Please share how this access benefits you. Submit a story.

Accessibility 


\section{STUDYING CHINESE POLITICS: \\ FAREWELL TO REVOLUTION?}

\section{Elizabeth J. Perry*}

Nearly three decades after Mao's death and more than fifteen years after the Tiananmen uprising, China is still a Leninist Party-state. In fact, one might well argue that the prospects for fundamental political transformation look less promising today than they did in the 1980s when leaders like Hu Yaobang and Zhao Ziyang spearheaded serious, if short-lived, efforts at political reform. ${ }^{1}$ But while political progress appears to have stalled, the Chinese economy continues to demonstrate impressive growth. Perhaps not surprisingly, then, scholarly interest in village elections and other signs of "democratization" has in recent years been somewhat eclipsed by debates about political economy: can China sustain high rates of economic growth without a clear specification of property rights, as has occurred in many formerly Communist countries? ${ }^{2}$ Will China succumb to the scourge of crony capitalism which has hamstrung a number of

* This paper was originally prepared for presentation at the conference to celebrate the Fiftieth Anniversary of the Fairbank Center for East Asian Research at Harvard University (December 2005). I am grateful to the conference organizers, Wilt Idema and Roderick MacFarquhar, as well as to the many conference participants who raised challenging comments and suggestions.

1 On the early post-Mao experiments in political reform, see Merle Goldman, Sowing the Seeds of Democracy in China: Political Reform in the Deng Xiaoping Era (Cambridge: Harvard University Press, 1994); Shiping Zheng, Party versus State in Post-1949 China: The Institutional Dilemma (New York: Cambridge University Press, 1997). On stalled political reform, see Joseph Fewsmith, China Since Tiananmen: The Politics of Transition (New York: Cambridge University Press, 2001).

2 Edward S. Steinfeld, Forging Reform in China: The Fate of State-Owned Industry (New York: Cambridge University Press, 1998); Jean C. Oi and Andrew G. Walder (eds), Property Rights and Economic Reform in China (Stanford: Stanford University Press, 1999). 
other developing countries? ${ }^{3}$ Or can strong state supervision keep the Chinese economic experiment on track-even as it moves steadily toward greater privatization and market freedom ${ }^{4}$ The answers to these questions are far from clear, in large part because we have such limited understanding of what holds the contemporary state structure together and thus allows the political system to function as effectively as it does. ${ }^{5}$ Moreover, there are no obvious counterparts elsewhere in the world to the situation that China currently faces. ${ }^{6}$

\section{The Limits of Comparison}

Although the field of Chinese politics has been greatly invigorated by its postMao re-engagement with comparative questions - ranging from civil society and democratization to property rights and rent-seeking-the fact is that contemporary China is not easily likened to other countries. Longstanding differences between Chinese and Soviet Communism have held major implications for the course of reform in the two countries. ${ }^{7}$ For example, in Mao's communes, unlike Stalin's collective farms, peasants were paid in collectively determined workpoints rather than in state wages, and land ownership was vested in the production team rather than the state. This meant that, although a return to family farming was eagerly embraced by many rural Chinese as a substitute for collective workpoints, issues of land ownership and control remain highly contentious - accounting for much of the conflict and

3 Lu Xiaobo, Cadres and Corruption: The Organizational Involution of the Chinese Communist Party (Stanford: Stanford University Press, 2000); David C. Kang, Crony Capitalism: Corruption and Development in South Korea and the Philippines (New York: Cambridge University Press, 2002); Melanie Manion, Corruption by Design: Building Clean Government in Mainland China and Hong Kong (Cambridge: Harvard University Press, 2004); Yan Sun, Corruption and Market in Contemporary China (Ithaca: Cornell University Press, 2004).

4 A positive assessment of Chinese state capacity is Dali L. Yang, Remaking the Chinese Leviathan: Market Transition and the Politics of Governance in China (Stanford: Stanford University Press, 2004); a negative assessment is Wang Shaoguang, "The Problem of State Weakness", Journal of Democracy, Vol. 14, No. 3 (2003), pp. 36-42. On the importance of state-led economic growth in developing countries more generally, see Atul Kohli, StateDirected Development (New York: Cambridge University Press, 2004).

5 Michel Oksenberg noted presciently in 1999 that "such previous depictions as 'totalitarianism,' a 'Leninist party state,' 'fragmented authoritarianism,' 'soft authoritarianism' or 'bureaucratic pluralism' miss the complexity of China's state structure on the eve of the twenty first century". Michel Oksenberg, "China's Political System: Challenges of the Twenty First Century", paper prepared for the Keio University International Symposium (December 1999).

6 Andrew G. Walder observes, "The longer China continues along its current trajectory of change, the less relevant are the prior examples of collapse and regime change in Eastern Europe and the USSR". Andrew G. Walder, "The Party Elite and China's Trajectory of Change", China: an International Journal, Vol. 2, No. 2 (September 2004), p. 190.

7 Pei Minxin, From Reform to Revolution: The Demise of Communism in China and the Soviet Union (Cambridge: Harvard University Press, 1994). 
violence sweeping the Chinese countryside today. But post-Mao authoritarianism also departs markedly from garden-variety authoritarian regimes where militarists gain power by means of coups d'état (rather than revolutionary mobilization) only to preside over bankrupt economies.

In some respects the "East Asian developmental state", which afforded a fruitful paradigm for the analysis of other rapidly growing economies in the region, seems a more promising framework for cross-national comparison than either Communism or run-of-the-mill authoritarianism. ${ }^{8}$ Yet, as is often noted, China's huge size and heterogeneity render facile comparisons with Japan-let alone the "Four Little Tigers" (Taiwan, South Korea, Singapore and Hong Kong) — of limited applicability. ${ }^{9}$

In terms of scale and diversity, the only case roughly comparable to China is of course India - which has also launched an ambitious program of economic liberalization in recent years (beginning in the 1980s, but with particular urgency following India's severe macroeconomic crisis of 1991). Yet the very different patterns of reform in the two Asian giants remind us of their starkly divergent histories and political systems. While both countries have enjoyed impressive economic growth in recent decades ${ }^{10}$ on virtually every standard indicator of economic success (gross national product, per capita income, industrialization, total factor productivity, exports, capital flows, external debt and the like) China has far outpaced its neighbor. Moreover, in terms of quality-of-life measures such as literacy and life expectancy, China also notably outperforms India.

Scholars who have attempted to explain this glaring discrepancy in the two countries' socio-economic development offer contradictory assessments of the impact of their respective political systems. ${ }^{11}$ Atul Kohli has attributed India's

8 Chalmers A. Johnson, MITI and the Japanese Miracle (Stanford: Stanford University Press, 1982); Meredith Woo-Cumings (ed.), The Developmental State (Ithaca: Cornell University Press, 1999); Robert Wade, Governing the Market: Economic Theory and the Role of Government in East Asian Industrialization (Princeton: Princeton University Press, 2004).

9 Some have therefore attempted to apply the model at the level of the local rather than the national Chinese state, see Jean C. Oi, Rural China Takes Off: Institutional Foundations of Economic Reform (Berkeley: University of California Press, 1999). In addition to size, however, there are other important differences between the PRC and the Four Tigers; for example, Chinese economic development has involved far greater foreign investment than was true for its East Asian neighbors. Mary Elizabeth Gallagher, Contagious Capitalism: Globalization and the Politics of Labor in China (Princeton: Princeton University Press, 2005), pp. 6-7; Yasheng Huang, Selling China: Foreign Direct Investment During the Reform Era (New York: Cambridge University Press, 2003).

10 Between 1980 and 1990, among 122 countries China's average economic growth rate was second-highest and India's was eleventh. Between 1990 and 2000, China's was again second-highest-among 140 countries-while India ranked tenth. T. N. Srinivasan, "Economic Reforms and Global Integration", in Francine Frankel and Harry Harding (eds), The India-China Relationship (New York: Columbia University Press, 2004), p. 236.

11 This is not surprising, inasmuch as larger cross-national studies have been unable to establish a significant correlation between either authoritarian regimes or democratic regimes and economic growth. Adam Przeworski, Michael E. Alvarez, Jose Antonio 
relatively lackluster reform results to interest-group gridlock stemming from its pluralist democracy. ${ }^{12}$ In a similar vein, T. N. Srinivasan notes that in China "the firm control held by the party made it much easier than in India to undertake and implement reforms ... the success of Chinese reforms has been in part due to China's being an authoritarian society". ${ }^{13}$ Jean Dreze and Amartya Sen, by contrast, stress that "while India has much to learn from China in the field of economic and social policy, the lessons do not include any overwhelming merit of its more authoritarian system". ${ }^{14}$ Jagdish Bhagwati, characterizing India as "the model that couldn't", argues nonetheless that "authoritarianism seems to be neither a necessary nor a sufficient condition for rapid growth", ${ }^{15}$

Yet the fact remains that it was during the height of Chinese authoritarianism - the Maoist era - that the foundations of contemporary growth were laid. Following upon a successful revolution that had been waged and won in the countryside, Mao and his comrades devoted unprecedented attention to the peasantry. That attention definitely had its dark side - as the horrendous Great Leap famine (following the introduction of rural communes) attested. Despite its peasant revolution, China suffered what economist Nicholas Lardy characterizes as a "puzzling" undervaluation of agriculture for most of the Maoist period. The result was chronic poverty for millions of rural dwellers. ${ }^{16}$ Even so, Mao's revolutionary regime must also be credited with important gains in improving the quality of life for much of its populace. Deeply flawed as the Chinese effort certainly was, the contrast with India is nonetheless stark. Bhagwati notes that, in comparison to China, "the Indian planners underestimated the productive role of better health, nutrition, and education and hence underspent on them". ${ }^{17}$ As Dreze and Sen acknowledge, "the larger success of the Chinese efforts at social progress has been, to a great extent, the result of the stronger political commitment of its leadership to eliminating poverty and deprivation". ${ }^{18}$ Rhoads Murphey, writing at the end of the Maoist period, attributed China's relative success (vis-à-vis India) in improving rural living standards to 'the government's commitment to this idea, and the power of central planning there, backed up by a revolutionary ideology and drawing on the immense force of a uniquely

Cheibub and Fernando Limonqi, Democracy and Development (New York: Cambridge University Press, 2000).

12 Atul Kohli, Democracy and Discontent: India's Growing Crisis of Governability (Cambridge: Cambridge University Press, 1990).

13 T. N. Srinivasan, "Economic Reforms", pp. 245, 259.

14 Jean Dreze and Amartya Sen, India: Economic Development and Social Opportunity (New York: Oxford University Press, 1995), p. 85.

15 Jagdish Bhagwati, India in Transition: Freeing the Economy (New York: Oxford University Press, 1993), pp. 20-21.

16 Nicholas R. Lardy, Agriculture in Modern China's Economic Development (New York: Cambridge University Press, 1983).

17 Jagdish Bhagwati, India in Transition, p. 36.

18 Jean Dreze and Amartya Sen, India, pp. 85-86. 
mobilized population". ${ }^{19}$ Without the PRC's investment during the $1950 \mathrm{~s}-70 \mathrm{~s}$ in rudimentary health care, education and infrastructure, all of which Mao personally championed as an expression of his revolutionary agenda and which he implemented (to varying degrees) through a series of mass campaigns, China's subsequent economic gains appear inconceivable..$^{20}$ As John Fairbank observed at the outset of the reform era, "This rural industrialization bears the stamp of Chairman Mao ... Tarnished or not, his monument is in the countryside". ${ }^{21}$

\section{Bringing the Revolution Back In}

The prevalent claim today that the Chinese revolutionary tradition is "fading as the country is set to become one of the major economic powers of the twenty-first century", ${ }^{22}$ may therefore be open to qualification. One might argue instead that China's stunning economic strides in the reform era can only be understood against the background of a revolutionary history that remains highly salient in many respects. To be sure, China's weakly articulated legal and financial institutions (closely linked to its revolutionary past) may in time pose insuperable barriers to continued economic vitality. Regardless of whether China's political system eventually proves to be a fetter on economic development, a number of elements of China's revolutionary legacy have facilitated recent gains. Despite valiant philosophical efforts to bid "farewell to revolution", ${ }^{23}$ China's revolutionary past has not yet been relegated to the dustbin of history. As Fairbank cautioned during the height of Deng Xiaoping's reform effort, "China for all its spectacular modernization still faces the problems and perils of the social revolution ..." ${ }^{24}$

The Chinese revolutionary tradition cannot be equated simply with Sovietstyle Communism, important as the Soviet example (with its Leninist Party-state and command economy) assuredly was. Mao's techniques of mass mobilization, born in revolutionary struggle but adapted to the tasks of post-revolutionary rule,

19 Rhoads Murphey, The Fading of the Maoist Vision: City and Country in China's Development (New York: Methuen, 1980), pp. 54-55.

20 On Mao's stated commitment to these goals, see Stuart Schram (ed.), Chairman Mao Talks to the People: Talks and Letters, 1956-1971 (New York: Pantheon, 1974), pp. 197-233; on the implementation via mass campaigns, see Michel C. Oksenberg, Policy Formulation in China: The Case of the 1957-1958 Water Conservancy Campaign (Columbia University $\mathrm{PhD}$ dissertation, 1969) and Charles P. Cell, Revolution at Work: Mobilization Campaigns in China (New York: Academic Press, 1977).

21 John King Fairbank, The United States and China, $4^{\text {th }}$ ed. (Cambridge: Harvard University Press, 1979), p. 449.

22 Proposal for conference to celebrate the fiftieth anniversary of the Fairbank Center for East Asian Research, Harvard University (December 2005).

23 Li Zehou and Liu Zaifu, Gaobie geming: huiwang ershishiji Zhongguo (Farewell to Revolution: Looking Back on Twentieth-Century China) (Hong Kong: Tiandi Book Company, 1997).

24 John King Fairbank, The Great Chinese Revolution, 1800-1985 (New York: Harper and Row, 1986), p. 351. 
lie at the heart of Chinese exceptionalism. Distinctions between Chinese and Russian variants of Communism, noted by Benjamin Schwartz more than half a century ago, ${ }^{25}$ help to make sense of China's current situation-which differs both from that of other post-Communist countries and from other developing countries, including India. Any serious study of the Chinese revolution and its aftermath, as Schwartz discovered, leads to an appreciation of the distinctions between Chinese and Soviet Communism - not to mention the even greater differences with countries that experienced neither social revolution nor Communism. ${ }^{26}$

The curious paradox whereby certain elements of China's revolutionary inheritance have actually furthered the stunningly successful implementation of market reforms has yet to be fully explored or explained by students of Chinese politics. To be sure, specific features of China's "economic miracle" have been linked to Maoist precedents. In particular, the initial dynamism of township and village enterprises was often attributed to legacies of the collective era such as commune and brigade enterprises and the continuing influence of cadre control. ${ }^{27}$ But while many scholars have plumbed the origins of (sometimes short-lived) local economic formations, few have tried to elucidate the defining elements of the larger political system within which such experiments have occurred. Taking a page from students of Latin America and Eastern Europe, China specialists routinely invoke the concept of "regime transition", despite the fact that the postMao period of PRC history has already lasted longer than the Maoist era that preceded it. Whether or not current political conditions persist for many more years, their distinguishing features are surely as worthy of careful attention and analysis as a previous generation of China scholars once showered upon the Maoist political system. ${ }^{28}$

25 Benjamin I. Schwartz, Chinese Communism and the Rise of Mao (Cambridge: Harvard University Press, 1951).

26 The opening of the Soviet archives in recent years has rekindled old debates about the extent to which the Chinese revolution simply replicated the Russian exemplar. For a partisan view that insists upon Soviet direction over virtually all aspects of the Chinese revolution, see Alexander Pantsov, The Bolsheviks and the Chinese Revolution, 1919-1927 (Richmond: Curzon, 2000); a more balanced picture which argues for considerable autonomy and innovation on the part of the Chinese is presented in S. A. Smith, A Road is Made: Communism in Shanghai, 1920-27 (Richmond: Curzon, 2000).

27 Jean C. Oi, Rural China Takes Off; Susan H. Whiting, Power and Wealth in Rural China: The Political Economy of Institutional Change (New York: Cambridge University Press, 2001).

28 A recent effort to explain élite dynamics under Mao (and Deng) in game-theoretic terms is Huang Jing, Factionalism in Chinese Communist Politics (New York: Cambridge University Press, 2000). For a textbook overview of both Maoist and post-Mao systems, see Kenneth Lieberthal, Governing China: From Revolution Through Reform, $2^{\text {nd }}$ ed. (New York: W. W. Norton, 2004). General essays on the topic by several political scientists can be found in Jonathan Unger (ed.), The Nature of Chinese Politics: From Mao to Jiang (Armonk: M. E. Sharpe, 2002). 
If it is "transitional", how has the current regime held onto power for three decades now, weathering a series of potentially destabilizing leadership successions (Mao to Hua to Deng to Jiang to $\mathrm{Hu}$ ) while presiding over what may well be the fastest sustained economic and socio-cultural transformation that any nation has ever undergone? A large part of the complex answer to this question lies in the retention - and reinvention - of many elements of China's revolutionary heritage. In moving from Maoist Communism to post-Mao authoritarianism, China has not simply jettisoned its revolutionary past as it "transits" toward a democratic future. Rather, a succession of post-Mao leaders have managed to fashion a surprisingly durable brand of "revolutionary authoritarianism" capable of withstanding challenges, including grievous and growing social and spatial inequalities, which would surely have undone less hardy regimes. The achievement is even more impressive when we remember that the geographical entity we now think of as "China" is of fairly recent vintage, a product of Qing imperial expansion that was reunited by first Nationalist and then Communist revolutionary armies. ${ }^{29}$

As Andrew Nathan confesses in a recent mea culpa, "After the Tiananmen crisis ... many China specialists and democracy theorists - myself among themexpected the regime to fall to democratization's 'third wave.' Instead, the regime has reconsolidated itself". ${ }^{30}$ Nathan proceeds to detail the ways in which the postMao state has managed to institutionalize the elite succession process so as to overcome factionalist tendencies and thereby avoid the political crisis that many had once presumed to be its inevitable fate. Recognizing that political stability hinges on social support (or at the very least social acquiescence) as well as on state institutionalization, Nathan concedes that "there is much evidence from both quantitative and qualitative studies to suggest that ... the regime as a whole continues to enjoy high levels of acceptance". ${ }^{31}$ To explain this puzzling degree of popularity for a government responsible for the Tiananmen massacre, Nathan points to the impact of various "input institutions"-local elections, letters-andvisits departments, people's congresses, administrative litigation, mass mediathat "enable citizens to pursue grievances without creating the potential to threaten the regime as a whole". ${ }^{32}$

Other explanations for the remarkable survival of China's non-democratic polity focus on particular social forces. Drawing upon an influential social science literature that stresses either the bourgeoisie or industrial labor as the

29 On Qing expansion, see Peter Perdue, China Marches West: The Qing Conquest of Central Eurasia (Cambridge: Harvard University Press, 2005). On the fragility of China's geographical, political and cultural unity, see James E. Sheridan, China in Disintegration (New York: Free Press, 1975); and Edward Friedman, National Identity and Democratic Prospects in Socialist China (Armonk: M.E. Sharpe, 1995).

30 Andrew J. Nathan, “Authoritarian Resilience”, Journal of Democracy, Vol. 14, No. 1 (2003), p. 6.

31 Andrew J. Nathan, “Authoritarian Resilience”, p. 13.

32 Andrew J. Nathan, “Authoritarian Resilience”, pp.14-15. 
vanguard of democratization, ${ }^{33}$ China scholars have observed that neither the rising class of entrepreneurs nor the declining class of state workers is pressing actively for political reform. Bound to the Party-state through a web of policies and institutions, the Chinese "bourgeoisie" expresses more interest in political stability than in political reform. ${ }^{34}$ Indeed, a substantial portion of private entrepreneurs, welcomed by Jiang Zemin's inclusiveness, have recently joined the Communist Party itself. ${ }^{35}$ And although state workers, pensioners and laid-off and migrant laborers have all launched dramatic protests in recent years, their criticisms have tended more to evince nostalgia for the Maoist past than enthusiasm for liberal democracy. ${ }^{36}$ Divided by region, generation and workplace conditions, aggrieved workers have been unable to form a united labor movement to press for improved labor standards - let alone a political movement to challenge the state. ${ }^{37}$

Revealing as these analyses are, their focus on the interests and inclinations of social forces seems inadequate as an overall explanation for China's "delayed democratization". ${ }^{38}$ Neither attitude surveys of enterprising business people nor

33 On the bourgeoisie, see Barrington Moore, Jr., Social Origins of Dictatorship and Democracy (Boston: Beacon, 1966); on the working class, see Dietrich Rueschemeyer, Evelyn Huber Stephens and John D. Stephens, Capitalist Development and Democracy (Chicago: University of Chicago Press, 1992); on both, see Ruth Berins Collier, Paths Toward Democracy (New York: Cambridge University Press, 1999).

34 Dorothy J. Solinger, "Urban Entrepreneurs and the State", in Arthur Lewis Rosenbaum (ed.), State and Society in China: The Consequences of Reform (Boulder: Westview, 1992), pp. 121-41; Margaret M. Pearson, China's New Business Elite: The Political Consequences of Economic Reform (Berkeley: University of California Press, 1997).

35 Bruce J. Dickson, Red Capitalists in China: The Party, Private Entrepreneurs, and Prospects for Political Change (New York: Cambridge University Press, 2003); Kellee S. Tsai, Capitalism without Democracy: The Politics of Private Sector Development in China (forthcoming).

36 Ching Kwan Lee, "The Revenge of History: Collective Memories and Labor Protests in Northeastern China", Ethnography, Vol. 1, No. 2 (December 2000), pp. 217-37, and "From the Specter of Mao to the Spirit of the Law: Labor Insurgency in China", Theory and Society, Vol. 31 (April 2002), pp. 189-228; Chen Feng, "Subsistence Crisis, Managerial Corruption and Labor Protests in China", The China Journal, No. 44 (July 2000), pp. 41-63; William Hurst and Kevin J. O'Brien, "China's Contentious Pensioners", The China Quarterly, No. 170 (June 2002), pp. 345-60; Cai Yongshun, "The Resistance of Chinese Laid-off Workers in the Reform Period", The China Quarterly, No. 170 (June 2002), pp. 327-44.

37 Ching Kwan Lee, "Pathways of Labour Insurgency", in Elizabeth J. Perry and Mark Selden (eds), Chinese Society: Change, Conflict and Resistance, $2^{\text {nd }}$ edition (London: Routledge, 2000), pp. 71-92.

38 Mary Gallagher has proposed that the way in which foreign direct investment took place in China-occurring before the advent of fundamental SOE reform or massive privatizationworked to "delay democracy" by fragmenting and forestalling potential political opposition, as enterprises and workers alike were forced to compete for capital and jobs. Mary E. Gallagher, "Reform and Openness: Why China's Economic Reforms Have Delayed Democracy", World Politics, Vol. 54, No. 3 (2002), pp. 339-72. 
interviews with restive workers are likely to shed as much light on the likelihood of regime change as a sober assessment of the techniques of rule perfected by the Chinese Communist state.

One key explanation for the survival of the PRC lies in the continuing strength of the Chinese Communist Party, especially its ability to recruit, monitor and reward the political élite. ${ }^{39}$ Barry Naughton and Dali Yang point out that "China has retained a core element of central control: the nomenklatura system of personnel management" and argue that "this nomenklatura personnel system is the most important institution reinforcing national unity" ${ }^{40}$ In differentiating the Chinese trajectory from that of failed Communist states, Andrew Walder observes that "China's Party hierarchy has survived unchanged". ${ }^{11}$ For Walder, cohesion among the top political leadership, state cadres and party members at large is the glue that holds the system together. ${ }^{42}$ While the composition of the political elite has changed dramatically since Mao's day (reflecting, among other things, an exponential growth in its educational credentials), its organizational structure has remained remarkably stable. ${ }^{43}$

Crucial as these élite dynamics are, the regime's future survival also rests upon its capacity to curb and channel potentially threatening social forces. Nathan's discussion of "authoritarian resilience" is a valuable step in the direction of understanding state-society relations in the current period, but his conclusion that "China has made a transition from totalitarianism to a classic authoritarian regime" 44 seems to underestimate the numerous continuities from the Maoist to the post-Mao period. As many have pointed out, the term "totalitarianism" does not capture the extent to which Mao's polity made room for social involvement. ${ }^{45}$ Thanks to its Maoist heritage, moreover, China's revolutionary authoritarianism is in some respects also quite unlike "a classic

39 Kjeld Erik Brødsgaard, "Management of Party Cadres in China", in Kjeld Erick Brødsgaard and Zheng Yongnian (eds), Bringing the Party Back In: How China is Governed (Singapore: Eastern Universities Press, 2004), pp. 57-91.

40 Barry J. Naughton and Dali L. Yang (eds), Holding China Together: Diversity and National Integration in the Post-Deng Era (New York: Cambridge University Press, 2004), p. 9. On the importance of the nomenklatura system during the 1980s, see Yasheng Huang, Inflation and Investment Controls in China: The Political Economy of Central-Local Relations During the Reform Era (New York: Cambridge University Press, 1996).

41 Andrew G. Walder, “The Party Elite”, p. 194.

42 Andrew G. Walder, "The Party Elite”, p.195-97.

43 Hong Yung Lee, From Revolutionary Cadres to Party Technocrats in Socialist China (Berkeley: University of California Press, 1991); Melanie Manion, Retirement of Revolutionaries in China (Princeton: Princeton University Press, 1993).

44 Andrew J. Nathan, “Authoritarian Resilience", p. 16.

45 Critiques of the totalitarian model as a characterization of Mao's China include Vivienne Shue, The Reach of the State: Sketches of the Chinese Body Politic (Stanford: Stanford University Press, 1988) and Andrew G. Walder, Communist Neo-Traditionalism (Berkeley: University of California Press, 1986). 
authoritarian regime". Although authoritarian regimes display considerable variation, Juan Linz notes that they generally share in common "the characteristic of low and limited political mobilization" ${ }^{46}$ Sidney Tarrow elaborates,

That authoritarian states discourage popular politics is implicit in their very definition. In particular, they suppress the sustained interaction of collective actors and authorities that is the hallmark of social movements ... Repressive states depress collective action of a conventional and confrontational sort, but leave themselves open to unobtrusive mobilization. ${ }^{47}$

Like other authoritarian societies, the PRC has certainly witnessed the development of a "hidden transcript" of unobtrusive dissent. ${ }^{48}$ But Communist China parts company with classic authoritarianism in having periodically encouraged - indeed compelled - its citizens to express their private criticisms publicly in the form of big-character-posters, struggle sessions, denunciation meetings, demonstrations and the like. The Cultural Revolution was the most dramatic, but not the last, expression of this state-sponsored effort at stimulating and shaping confrontational politics.

\section{"Revolutionary Authoritarianism": From Divide and Conquer to Divide and Rule}

The post-Mao leadership, following the example set by the Great Helmsman, has proven adept at the art of creating coalitions with, and cleavages among, key social elements as a means of stimulating popular political involvement so as to bolster its own political hegemony. This core feature of China's revolutionary authoritarianism reflects hard-won lessons learned in the course of decades of life-or-death struggles. As Chen Yung-fa details in his insightful study of the wartime base areas, the Chinese Communists' methods of revolutionary mobilization (and de-mobilization) comprised a remarkably flexible and highly effective strategy, perfected over many years of trial-and-error practice in diverse geographical settings ${ }^{49}$ Despite all the calls for nationalism and national unity issued by Mao and his comrades during the War of Resistance against Japan, their real recipe for revolutionary success lay in identifying and intensifying domestic tensions in a manner that enhanced the power of the emerging Communist Party-state. A wide variety of social contradictions were reinterpreted as "class struggles" that required CCP intervention and direction. Chen aptly characterized the Communists' approach as one of "controlled polarization". ${ }^{50}$

\footnotetext{
46 Juan J. Linz, Totalitarian and Authoritarian Regimes (Boulder: Lynn Reinner, 2000), p. 269.

47 Sidney Tarrow, Power in Movement: Social Movements, Collective Action and Politics (New York: Cambridge University Press, 1994), pp. 92-93.

48 James C. Scott, Domination and the Arts of Resistance: Hidden Transcripts (New Haven: Yale University Press, 1990).

49 Chen Yung-fa, Making Revolution: The Communist Movement in Eastern and Central China, 1937-1945 (Berkeley: University of California Press, 1986).
}

50 Chen Yung-fa, "Making Revolution”, p. 11. 
The history of state-society relations under the PRC is largely the application of this revolutionary lesson to the task of regime consolidation. Nationalistic rhetoric continued to be tempered by a politics of division. As Chen observes, "there was no sharp break between wartime and postwar Chinese communism". ${ }^{51}$ A strategy of divide-and-conquer was adapted to one of divideand-rule. The key institutions of the Maoist era such as work units (danwei) which isolated the industrial labor force, people's communes (renmin gongshe) that enforced rural self-sufficiency, job allocations (fenpei) that rendered intellectuals dependent upon state favor, labor insurance (laobao) that bestowed generous welfare benefits upon permanent workers at state-owned enterprises while leaving the majority of the workforce unprotected, personnel dossiers (dang'an) which marked citizens with "good" or "bad" political records, household registrations (hukou) that separated urban and rural dwellers, class labels (jieji chengfen) that categorized people into "five kinds of red" (hong wulei) and "five kinds of black" (hei wulei) - all served to divide society and foster subservience to the state. ${ }^{52}$

Contrary to what some have suggested, this social fragmentation and dependence on the state did not amount to a "totalitarianism" that robbed the Chinese populace of a capacity for protest — quite the opposite. ${ }^{53}$ Just as "controlled polarization", waged under the unifying banner of nationalism, facilitated a peasant revolution of staggering size and scope, so it also provided the framework for the huge mass movements for which the People's Republic of China has been renowned. ${ }^{54}$ Participants in mass criticisms and demonstrations of various sorts routinely organized themselves along officially prescribed lines. Even in the post-Mao "democracy movement" of 1989, often characterized as the

51 Chen Yung-fa, "Making Revolution", p. 517. Similarly, Edward Friedman refers to Mao's style of rule as "war communism". See Edward Friedman, National Identity, pp. 208-09.

52 For the operations of these institutions in the Maoist era, see William L. Parish and Martin King Whyte, Village and Family in Contemporary China (Chicago: University of Chicago Press, 1978); Martin King Whyte and William L. Parish, Urban Life in Contemporary China (Chicago: University of Chicago Press, 1984); Richard C. Kraus, Class Conflict in Chinese Socialism (New York: Columbia University Press, 1981); Andrew G. Walder, Communist Neo-Traditionalism; T. J. Cheng and Mark Selden, "The Origins and Social Consequences of China's Hukou System”, The China Quarterly, No. 139 (September 1994), pp. 644-68; Lu Xiaobo and Elizabeth J. Perry (eds), Danwei: The Changing Chinese Workplace in Historical and Comparative Perspective (Armonk: M. E. Sharpe, 1997).

53 Elaboration of this argument can be found in Elizabeth J. Perry, "Shanghai's Strike Wave of 1957", The China Quarterly, No. 137 (March 1994), pp. 1-27; and Elizabeth J. Perry and Li Xun, Proletarian Power: Shanghai in the Cultural Revolution (Boulder: Westview Press, 1997).

54 Mao's effort to reconcile the ideological vision of nationalism with the instrumental tactics of polarization can be seen in his 1938 essay, "The Role of the Chinese Communist Party in the National War", in Selected Readings from the Works of Mao Tsetung (Peking: Foreign Languages Press, 1971), pp. 138-59. On mass campaigns in the PRC, see Gordon A. Bennett, Yundong: Mass Campaigns in Chinese Communist Leadership (Berkeley: University of California Center for Chinese Studies, 1976). 
most "autonomous" of contemporary Chinese demonstrations, protesters marched through Tiananmen Square behind banners announcing their state-designated units (for example, the Capital Iron and Steel Works, or the Propaganda Department of the Central Committee). This reliance upon state-supplied organizations and identities permitted rapid mobilization (and de-mobilization) at the same time as it undercut the potential for collective protest to escalate into a fundamental challenge to the state.

Although Maoist institutions have undergone substantial transformation in the reform era, earlier practices retain significant residual power. ${ }^{55}$ Today urban registrations may be purchased by the well-to-do as well as inherited, but they remain a crucial means for gaining access to educational opportunity. Jobs are now often procured via market mechanisms rather than by state fiat, yet personnel dossiers continue to play a role in promotions, sensitive assignments, and the like. The changing operations of these Maoist institutions, along with the emergence of new organizations, such as "homeowners' associations" (yezhu hui) and "communities" (shequ) to replace residents' committees, demand our careful attention and analysis if we are to understand the multiple means, coercive as well as cooptative, by which the Chinese state manages to hold its restive citizenry in check.

It is worth reiterating that these mechanisms have never prevented the Chinese populace from demonstrating an impressive appetite for contentious politics - whether in Mao's day or today. ${ }^{56}$ Mao himself of course inspired a good deal of just such activity through the purposeful stirring up of popular contradictions and criticisms. In the post-Mao era as well, central leaders have sometimes (implicitly if not explicitly) encouraged ordinary people to take to the streets as a means of furthering élite agendas. ${ }^{57}$ Although social groups often respond to state-initiated opportunities by airing complaints that exceed official bounds, both the mobilization and the de-mobilization of mass movements proceed along state-designated occupational and territorial lines and thus reinforce social cleavages in favor of state control. ${ }^{58}$

In every decade since the founding of the PRC, state power has appeared to have been challenged: during the Hundred Flowers Campaign of 1956-57, the

55 Dorothy J. Solinger, Contesting Citizenship in Urban China (Berkeley: University of California Press, 1999).

56 Elizabeth J. Perry, "To Rebel is Justified: Cultural Revolution Influences on Contemporary Chinese Protest", in Kam-yee Law (ed.), Beyond Purge and Holocaust: The Chinese Cultural Revolution Reconsidered (Palgrave Press, 2003), pp. 262-81.

57 Notable examples include Deng Xiaoping and the Democracy Wall movement of 1978-79; $\mathrm{Hu}$ Yaobang and the student protests of 1986-87; Zhao Ziyang and the Tiananmen unrest of 1989; Hu Jintao and anti-Japanese demonstrations in 1999 and later. See Elizabeth J. Perry, Challenging the Mandate of Heaven: Social Protest and State Power in China (Armonk: M. E. Sharpe, 2002), Introduction, pp. ix-xxxii.

58 Sebastian Heilmann, "The Social Context of Mobilization in China: Factions, Work Units and Activists During the 1976 April Fifth Movement", China Information, No. 8 (Winter 1993-94), pp. 1-19. 
Cultural Revolution of 1966-69, the Democracy Wall Movement of 1978-79, the Tiananmen uprising of 1989 and the Falun Gong demonstrations of 1999. But in each case the central leadership (while invoking the rhetoric of national unity) has adroitly applied the techniques of divide and rule. Public security forces, augmented by military units if necessary, work to ensure that various social groups - especially workers and intellectuals - do not join hands. ${ }^{59}$ During the Hundred Flowers movement, the massive strikes that swept through China's factories remained isolated from the big-character-poster campaign being waged on university campuses. That summer the suppression of the Anti-Rightist Campaign (directed by Deng Xiaoping) applied different criminal "hats" to worker and student activists-symbolizing their distinctive political status. Although the early weeks of the Cultural Revolution saw student Red Guards take their struggles to the factories, within a few months they were prohibited from such activities; and eventually the tide was reversed as propaganda teams of workers, often accompanied by PLA soldiers, moved into the schools to restore order. A decade later, the harsh fifteen-year sentence meted out to Democracy Wall activist Wei Jingsheng in 1979 reflected his embodiment of dual worker and intellectual status more than his incendiary calls for a "fifth modernization" of democratic freedoms. In 1989, the very different punishments suffered by students and workers active in the protests again illustrates the Deng Xiaoping regime's divide and rule strategy (student leaders were detained and then released while worker leaders were often executed).

Long segregated into separate state-created categories, citizens themselves are often inclined to accept these divisions as a normal part of the political order. Consider the following incident. In the winter of 1986-87, large-scale student demonstrations broke out in Shanghai after police brutality during a concert by an American rock group. During the concert, several college students who had responded enthusiastically to the performers' invitation to dance in the aisles were hauled outdoors and beaten. Fellow students, and then workers, poured into the streets to protest against the police action. On orders from Jiang Zemin, then mayor of Shanghai, barricades were erected at People's Square to prevent workers from entering the ranks of the student protesters. Only those with valid student IDs were permitted inside the police cordon. Workers massed just outside the barricades, tossing in bread and cigarettes and shouting "Younger brothers, your elder brothers support you!" To defuse this potentially explosive situation, Jiang Zemin went in person to the university of the students who had been roughed up to deliver an apology on behalf of the city government. He explained to the tense all-campus assembly that the police had mistaken the students for workers, which was the reason they had reacted so harshly. Even more surprising in this self-proclaimed "workers' state" was the fact that the professors and

59 On the mechanics of state suppression, see Murray Scot Tanner, Chinese Government Responses to Rising Social Unrest (Santa Monica: Rand, 2005); Timothy Brook, Quelling the People: The Military Suppression of the Beijing Democracy Movement (Stanford: Stanford University Press, 1998). 
students in attendance reported that they found nothing inappropriate in the mayor's explanation. ${ }^{60}$

Jiang Zemin's skillful deployment of the familiar strategy of divide and rule won him the attention of Deng Xiaoping. After being tapped for central leadership during the 1989 protests, Jiang put these techniques to effective use in responding to a wide range of potential challenges. His regime dealt extremely harshly with movements (such as the China Democracy Party and Falun Gong) that boasted a socially and regionally diverse membership but showed considerable leniency toward conflicts that were more homogeneous in composition and locale. Indeed, Jiang's government even endorsed and encouraged some single-issue protests (for example, the student demonstrations against the US bombing of China's Belgrade embassy in the spring of 1999). ${ }^{61}$

While Jiang Zemin relied upon familiar revolutionary methods of "controlled polarization" to tame social forces, the inclusive ideology that he attempted to formulate (and to propagate through a series of Maoist-style ideological campaigns) reinforced the official stress on national unity. Jiang's Three Represents - by which the Communist Party is supposed to serve as the representative of "advanced productive forces, advanced culture, and the interests of the overwhelming majority of the people"-was an effort to update Mao's "mass line". Moreover, as Jiang's own rise to the pinnacle of power was tied to the state's verdict on the 1989 protest movement as a "counter-revolutionary rebellion", his scope for ideological innovation was limited.

Jiang Zemin's much-publicized campaign against Falun Gong resorted to divisive revolutionary rhetoric by branding the "evil cult" as "counterrevolutionary". ${ }^{62}$ Jiang's successor as General-Secretary of the Chinese Communist Party, Hu Jintao, has also repeatedly summoned revolutionary symbolism in justifying his party's claim to rule. On a visit to the site of the former Jiangxi Soviet in the summer of 2003, Hu enjoined officials at all levels of the party to "carry on the revolutionary tradition". As Hu put it, "Comrade Mao Zedong and other revolutionaries of the elder generation not only made

60 Interviews in Shanghai, January 1987. That workers and intellectuals continue to experience markedly different treatment at the hands of state authorities (and in the eyes of the public) was demonstrated graphically by the infamous Sun Zhigang case in 2003. Sun, a university graduate who was traveling without identification papers, was arrested when the police mistook him for a migrant laborer. After Sun was beaten to death while in police custody, the media, intellectual commentators and state officials all made much of the fact that a university graduate had been treated so terribly. Had Sun been an uneducated migrant worker, as the police originally suspected, his brutal death would surely not have elicited the same public outcry. A detailed discussion of the media coverage of this case can be found in a forthcoming book by Zhao Yuezhi, to whom I am grateful for this interpretation.

61 Jeffrey N. Wasserstrom, “The Year of Living Anxiously: China's 1999”, Dissent (Spring 2002); Elizabeth J. Perry, Challenging the Mandate of Heaven, Introduction.

$62 \quad$ Notice on Various Issues Regarding Identifying and Banning of Cultic Organizations (Beijing: Ministry of Public Security of The People's Republic of China, 2000), reprinted in "Religion and Public Security in China, 1999-2002", Chinese Law and Government, Vol. 36, No. 2 (2003). 
historical achievements by realizing national independence and liberation, but also bequeathed to us precious spiritual wealth". A front-page article in People's Daily elaborated on Hu's remarks: "such revolutionary spirit and tradition, which were fostered through arduous struggles, provide strength for overcoming difficulties and risks of all kinds in our way forward". ${ }^{63} \mathrm{Hu}$ 's subsequent slogan of "building a harmonious society" has not displaced the recourse to revolutionary mobilization techniques.

The 2003 battle waged against SARS was a telling example of how the new leadership adapted Maoist tactics to cope with contemporary challenges. In what $\mathrm{Hu}$ Jintao dubbed the "People's War against SARS", neighborhood committees were charged with enforcing strict sanitation standards within their jurisdictions. Activists (some dressed as that passé paragon of Maoist virtues, Lei Feng) went from door to door to ensure that the public adhered to the government's guidelines. ${ }^{64}$ Reminiscent of public health campaigns in Mao's day (such as the campaign against schistosomiasis or the campaign against the Four Pests), the anti-SARS effort attested to the continuing capacity of the regime to mobilize its citizenry behind state-initiated projects.

Slogans recalled the patriotic battle cries of an earlier era: "Activate the whole Party, mobilize the entire populace, win the war of annihilation against SARS!"; "Enlarge the national spirit, unite with one heart to battle SARS!" Despite the calls for unity, the tactics were draconian: tens of thousands of people were forcibly placed under strict quarantine; countless civet cats, chickens and other possible disease-carriers were slaughtered with little concern for the consequences, and so on. ${ }^{65}$ Those who succumbed to the disease were designated "national heroes" and "martyrs", and their survivors became eligible to receive the same state-conferred benefits (free schooling, generous medical insurance and the like) that this exalted status had long conferred on the dependents of "revolutionary martyrs". ${ }^{66}$ While the PRC's response to SARS was understandably criticized by some policy analysts for its "out-dated mode of

63 Renmin ribao (People's Daily) (3 September 2003).

64 "President Hu Jintao Calls for a 'People's War' Against SARS”, Xinhua Report (Tianjin: 1 May, 2003), translated in Chinese Law and Government (July/August 2003), p. 44; Joseph Kahn, "The SARS Epidemic", New York Times (25 April 2003); Elisabeth Rosenthal, "SARS Makes Beijing Combat an Old but Unsanitary Habit", New York Times (28 May 2003).

65 Over 30,000 people were quarantined with official government approval, but many others were placed under unauthorized quarantine by their local neighborhood committees. On the official process, see Xinghuo Pang, Zhonghan Zhu, Fujie Xu, Jiyong Guo, Xiaohong Gong, Donglei Liu, Zejun Liu, Daniel P. Chin and Daniel R. Feikin, "Evaluation of Control Measures Implemented in the SARS Outbreak in Beijing, 2003", Journal of the American Medical Association, Vol. 290, No. 24 (24/31 December 2003), pp. 3215-221; for the unofficial situation, see Taru Salmenkari, "SARS Prevention Campaign and the Limits of Media Mobilization", unpublished paper.

66 Renmin ribao (People's Daily), 4, 14, 29 and 30 July 2003. 
crisis management", ${ }^{67}$ in retrospect the effort to resuscitate seemingly anachronistic campaign methods for new purposes appears to have been quite successful. Joan Kaufman, highlighting the Chinese government's ability "to detain and isolate citizens", observes that the resort to Maoist-style public campaigns "was precisely what was required to put in place the series of preventive measures that broke the chain of transmission". ${ }^{68}$ A summary article in the Journal of the American Medical Association concludes approvingly that "the multiple control measures implemented in Beijing likely led to the rapid resolution of the SARS outbreak". ${ }^{69}$

The current PRC leadership is not content simply to make instrumental use of Maoist mobilization tactics. It also tries actively to instill a sense of revolutionary continuity among officials and ordinary people alike. Following $\mathrm{Hu}$ Jintao's visit to Jiangxi, a branch of the Central Party School was opened at the site of Mao's first rural revolutionary base area in the Jinggangshan highlands, so that cadres could reconnect with their revolutionary roots (while "roughing it" at one of the two three-star hotels located within the spacious party school compound!).$^{70}$ For ordinary citizens, "red tourism" (hongse lüyou) to the sacred sites of Mao's revolution is being vigorously promoted as a means both of improving the party's public image (by showcasing its past struggles and sacrifices) and as a vehicle for pumping much needed revenues into what remain some of the poorest regions of the countryside.

With such state-promoted glorification of the revolutionary tradition, it is not surprising that contemporary protesters should attempt to capitalize on this "precious spiritual wealth" to further their own purposes. At the Anyuan coal mine in Jiangxi, where in 1922 Mao Zedong, Li Lisan and Liu Shaoqi had organized the first working-class branch of the Chinese Communist Party and instigated the first successful industrial strike under CCP direction, retired miners in 2004 called attention to that history: "During the years of revolutionary struggle, Anyuan workers suffered and sacrificed for the sake of the Chinese revolution ... Under the reforms, thanks to the exertions of our generation of miners, the enterprise has profited and prospered and yet we have not enjoyed the fruits of reform. Our wages have been cut and our pensions are very, very meager". 71

67 Tony Saich, "Is SARS China's Chernobyl or Much Ado About Nothing?" in Arthur Kleinman and James L. Watson (eds), SARS in China: Prelude to Pandemic? (Stanford: Stanford University Press, 2006), p. 89.

68 Joan Kaufman, "SARS and China's Health-Care Response: Better to be Both Red and Expert!" in Arthur Kleinman and James L. Watson (eds), "SARS in China", pp. 66-67.

69 Xinghuo Pang et al., "Evaluation of Control Measures", p. 3221.

70 Visit to Jinggangshan, Jiangxi, in summer 2005.

71 Laodong tiaojian zui cha, gongzuo zui jianku, zui weixian, dui guojia he qiye gongxian zui da de pingkuang tuixiu zhigong tuixiu yanglaojin dixia (The Dwindling Pensions of Retired Pingxiang Miners Whose Labor Conditions Were the Worst, Whose Work Was the Most Difficult and Dangerous, Yet Whose Contribution to Country and Enterprise Was the Greatest), unpublished protest manifesto (Anyuan, Jiangxi, 2004). 
Today's protesters draw not only rhetorical but also practical inspiration from revolutionary precedents. Faced with the threat of bankruptcy triggered by post-Mao industrial policies, disgruntled workers have once again been organizing militia units to protect their factories - in conscious imitation of the revolutionary exemplar. ${ }^{72}$ But this time they hope to "liberate" their workplaces from forced closures by the Party. Political scientist Feng Chen reports on a recent scene at a Shanghai plastics factory:

As some workers proudly describe it, their action of defending the factory is similar to that of their predecessors on the eve of the Communist takeover in 1949 when pro-Communist workers formed "worker guard teams" [gongren jiuchadui] to protect factories from sabotage by the Guomindang. Ironically, however, the workers are now using the same method to ward off capitalistic takeovers endorsed by a party-state that still labels itself socialist. ${ }^{73}$

Similar confrontations, pitting "revolutionary" workers against "reformist" government authorities, have taken place in many other parts of the country as well. Despite the use of revolutionary nomenclature and symbolism, such labor protests are not proto-revolutionary movements poised to topple the state. Rather, aggrieved workers draw creatively upon the language and legacy of the Communist revolution in an effort to shame the Party-state into living up to the promises of its own "revolutionary tradition".

\section{The Consequences of Revolutionary Authoritarianism}

The tendency for protesters to take cues from officially approved symbols of authority can be found in any polity, but is especially pronounced in authoritarian systems where the state exercises a virtual monopoly over political discourse. In such contexts, the clever appropriation and inversion of officially sanctioned slogans and practices is a prominent feature of (often unobtrusive) protest behavior. ${ }^{74}$ Under the revolutionary authoritarianism of the PRC, where mass mobilization has been a hallmark of state-society relations, the practice of "waving the red flag to oppose the red flag" has been honed to a high - and often highly ironic - art form. ${ }^{75}$ Sebastian Heilmann observed this phenomenon among workers seeking wage hikes and improved workplace conditions during the Cultural Revolution:

\footnotetext{
72 For the revolutionary history of the worker pickets, see Elizabeth J. Perry, Patrolling the Revolution: Worker Militias, Citizenship and the Modern Chinese State (Lanham: Rowman and Littlefield, 2006).

73 Feng Chen, "Industrial Restructuring and Workers' Resistance in China", Modern China, Vol. 29, No. 2 (April 2003), p. 250. In the countryside as well, there are reports of unruly militias challenging state authority. See, for example, China Focus, Vol. 6, No. 9 (1 September 1998), p. 4.

74 James C. Scott, Domination and the Arts of Resistance.

75 Patricia M. Thornton, "Framing Dissent in Contemporary China: Irony, Ambiguity and Metonymy", The China Quarterly, No. 171 (September 2002), pp. 661-81.
} 
In most cases, angry workers skillfully made use of official campaign slogans to camouflage their "economistic" interests. Officially approved slogans like "Down With the Capitalist Roaders" were deliberately used as a means of confronting an unresponsive leadership ... Under the cloak of rebellion against "revisionist" forces, diverse groups of workers used the opportunity to complain about specific grievances in their respective work units and about economic hardship. ${ }^{76}$

The turmoil of the Cultural Revolution originated in part from Mao Zedong's effort to stem the tide of "revisionism" by cultivating "revolutionary successors" among the younger generation. Although student Red Guards (and other social groups) strayed far from Mao's vision of proper revolutionary activity, they were nonetheless constrained by the fact that their "revolution" had been launched by the Chairman of the Communist Party himself.

Once Mao was gone, it became commonplace among students of Chinese politics to suggest that contemporary popular protest exhibits a degree of spontaneity and independence that marks it as qualitatively different from the mobilized movements of Mao's day. Despite the pivotal role of Deng Xiaoping in first encouraging and then suppressing the Democracy Wall movement of 1978-79, foreign observers hailed it as an unprecedented expression of citizenbased pressures for democratization..$^{77} \mathrm{~A}$ decade later, the Tiananmen uprising of 1989 led many scholars to express excitement about what they saw as a fundamental break with previous campaign-style modes of popular involvement. Andrew Walder described participation in the Tiananmen uprising of 1989 as "something new on the political scene: massive, independent, popular protests. The old mode of regimentation and elite-sponsored turbulence has been broken, and Chinese politics appears to have entered a new era". ${ }^{78}$ Similarly, Wang Shaoguang argued that "the protest movement of 1989 marked a turning point of changing class relations ... the working class in China is no longer a pillar of continuity but a force for change". ${ }^{79}$ The notion of a qualitative transformation was picked up by general comparativists as well. Jack Goldstone wrote of 1989 that "unlike other confrontations that involved mainly intellectuals, such as the

76 Sebastian Heilmann, "Turning Away from the Cultural Revolution: Political Grass-Roots Activism in the Mid-Seventies", Center for Pacific Asia Studies at Stockholm University, Occasional Paper, No. 28 (September 1996), pp. 11-13.

77 James D. Seymour (ed.), The Fifth Modernization: China's Human Rights Movement, 197879 (Stanfordville: Human Rights Publishing Group, 1980); John Fraser, The Chinese: Portrait of a People (New York: Summit, 1980); David S. G. Goodman, Beijing Street Voices: The Poetry and Politics of China's Democracy Movement (London: Marion Boyars, 1981). A more nuanced assessment can be found in Andrew J. Nathan, Chinese Democracy (Berkeley: University of California Press, 1985).

78 Andrew G. Walder, "Urban Industrial Workers: Some Observations on the 1980s", in Arthur Lewis Rosenbaum (ed.), State and Society in China: The Consequences of Reform (Boulder: Westview, 1994), p. 104.

79 Wang Shaoguang, "Deng Xiaoping's Reform and the Chinese Workers' Participation in the Protest Movement of 1989", Research in Political Economy, Vol. 13 (1992), pp. 163-97. 
Hundred Flowers Movement, or other events that were in some sense orchestrated by the regime, such as the Cultural Revolution, Tiananmen marked the first time that intellectuals and popular elements acted independently to challenge the regime". ${ }^{80}$

More than fifteen years after Tiananmen, however, it is increasingly difficult to regard that confrontation as having signaled a dramatic turning point in statesociety relations. Sober reflections on the activities of Tiananmen protestersincluding retrospectives by some of the principals themselves-question the extent to which their behavior in the spring of 1989 constituted a genuine rupture with earlier modes of protest. As Tiananmen activist Liu Xiaobo conceded in a bitterly impassioned essay entitled "That Holy Word: 'Revolution"”,

Most of the resources and methods we made use of to mobilize the masses were ones that the Communist Party itself had used many times before ... As soon as we began our revolution, we became extremely conceited-just as if we had reverted to the time of the Cultural Revolution and felt ourselves to be the most revolutionary. As soon as we joined the 1989 protest movement, we considered ourselves to be the most democratic. After all, had we not fasted for democracy and devoted ourselves to it and made sacrifices for it? ... Our voice became the only truth. We felt as though we possessed absolute power. ${ }^{81}$

Liu's reflections are a stinging indictment of the Tiananmen protest as an undemocratic movement that unwittingly recreated many of the core features of Chinese Communist revolutionary culture. The searing experience of the stateorchestrated Cultural Revolution in particular, according to Liu Xiaobo, continued to inhibit the development of a genuinely democratic perspective.

Despite its bloody suppression, the 1989 uprising did not end popular protest in China, and many scholars continue to see the signs of an imminent breakthrough in state-society relations in the most recent ferment. Kevin O'Brien and Li Lianjiang see the tendency of restive farmers to cite official government regulations and policies in justifying their (sometimes unruly) behavior as "rightful resistance" and argue that it reflects a growing sense of "citizenship rights" among ordinary Chinese. ${ }^{82}$ David Zweig also detects an emerging "rights conscious peasantry". ${ }^{83}$ Pei Minxin, discussing the impact of rapid economic

80 Jack A. Goldstone, "Analyzing Rebellion and Revolution: A Reply to the Critics", Contention (1994), pp. 177-98.

81 Liu Xiaobo, "That Holy Word, 'Revolution'”, in Jeffrey N. Wasserstrom and Elizabeth J. Perry (eds), Popular Protest and Political Culture in Modern China, $2^{\text {nd }}$ edition (Boulder: Westview, 1994), pp. 315, 318.

82 Kevin O'Brien and Li Lianjiang, Rightful Resistance in the Chinese Countryside (New York: Cambridge University Press, 2006). For a more cautious assessment of contemporary rural protest, noting the continuities with peasant unrest in previous periods of Chinese history, see Thomas P. Bernstein and Xiaobo Lu, Taxation without Representation in Contemporary Rural China (New York: Cambridge University Press, 2003).

83 David Zweig, "To the Courts or to the Barricades: Can New Political Institutions Manage Rural Conflict?", in Elizabeth Perry and Mark Selden (eds), Chinese Society, p. 132. 
development as well as the implementation of legal reforms such as the Administrative Litigation Law, notes a "rising rights consciousness" within Chinese society at large. Summing up the history of the reform era with an eye toward the future, Pei predicts that "China's incipient opposition is likely to become more resilient, sophisticated and adept in challenging the regime as the conditions for democratic resistance further improve". ${ }^{84}$ Merle Goldman argues that "by the century's end the sense of rights consciousness ... had spread ... beyond intellectual and elite circles ... to the population at large ... [T] he transition from comrade to citizen in the People's Republic of China has begun". ${ }^{85}$ This optimistic outlook pervades much of the journalistic reporting on China as well; a recent Business Week article, for example, speaks glowingly of "a new labor-rights revolution sweeping China". ${ }^{86}$

Such arguments about the growth of Chinese social power, fueled by newfound conceptions of citizenship, dovetail with a prevalent view of the postMao state as a pale shadow of its predecessor-sapped of both the desire and the capacity fully to control society at large. David Shambaugh observes: "If one of the hallmarks of the Maoist state was the penetration of society, then the Dengist state was noticeable for its withdrawal. The organizational mechanisms of state penetration and manipulation were substantially reduced or dismantled altogether". ${ }^{87}$ Ding Xueliang characterizes the post-Mao state as gripped by a legitimacy crisis that and a "gradual functional and organizational decay of the massive party-state machinery". ${ }^{88}$ The result, Pei Minxin concludes, is "the erosion of state capacity in China". ${ }^{89}$

I am skeptical both of such accounts of state withdrawal or weakness and of claims of a new and growing awareness of rights-based citizenship in contemporary China. It is true that protesters today routinely invoke the language of "rights" in pressing their demands, as is only to be expected in the light of widespread government propaganda promoting the importance of such stateconferred "rights". ${ }^{90}$ Bookstores these days are stocked with pamphlets detailing

84 Pei Minxin, "Rights and Resistance", in Elizabeth Perry and Mark Selden (eds), Chinese Society, pp. 40-43; see also Pei Minxin, "Citizens v. Mandarins: Administrative Litigation in China”, The China Quarterly, No. 152 (December 1997), pp. 832-62.

85 Merle Goldman, From Comrade to Citizen: The Struggle for Political Rights in China (Cambridge: Harvard University Press, 2005), pp. 222-23.

86 Dexter Roberts, “Waking Up to Their Rights”, Business Week (22/29 August 2005), p. 123.

87 David Shambaugh, "The Chinese State in the Post-Mao Era", in David Shambaugh (ed.), The Modern Chinese State (Cambridge: Cambridge University Press, 2000), p. 183.

88 X. L. Ding, The Decline of Communism in China (New York: Cambridge University Press, 1994), p. 200.

89 Pei Minxin, China's Trapped Transition: The Limits of Developmental Autocracy (Cambridge: Harvard University Press, 2006)

90 There is, of course, a serious issue about the meaning of the Chinese term quanli ("rights"). Stephen C. Angle delineates what he characterizes as "a distinctive Chinese discourse about 
government laws, policies and regulations; the air waves are filled by radio talk shows that advise listeners on how to ensure that regulations are enforced and contracts are fulfilled; newspapers are replete with legal advice columns for aggrieved citizens; and so on. ${ }^{91}$ But post-Mao state proclamations heralding "reform" and "legal rights" bear a certain parallelism to Maoist state propaganda harping on "revolution" and "class struggle". Just as protesters during the Maoist era borrowed the then hegemonic language of class in pressing their demands, so protesters today adopt the currently hegemonic language of rights in framing their grievances. This phenomenon, in my view, is "rules consciousness" rather than "rights consciousness". ${ }^{22}$ Instead of indicating some novel expression of proto-democratic citizenship or state vulnerability, the continuing adherence to rules consciousness seems to me to reflect a seasoned sensitivity on the part of ordinary Chinese to (changing yet still powerful) top-down signals emanating from the state..$^{33}$

Revolutionary authoritarianism demands active engagement (rather than "exit") by society, in a manner authorized by the state. People are encouraged to express "voice" as well as "loyalty" ${ }^{4}$ so long as they play by the official rules of the game. For these reasons, although protest in Communist China has been more frequent and widespread than in other authoritarian settings, ultimately it has proven less politically destabilizing. Precisely because protest in the PRC is both routine and officially circumscribed, once the top leadership decides upon a course of repression most of the populace is quick to fall into step. The crackdown on Tiananmen protesters in 1989 or Falun Gong demonstrators a decade later was after all a familiar drill harking back to the Anti-Rightist Campaign of 1957, the military suppression of Cultural Revolution mass activism in 1968, the clearing of Tiananmen Square in April 1976 and the clampdown on

rights" in his illuminating book, Human Rights and Chinese Thought (New York: Cambridge University Press, 2002).

91 On the limited scope of these legal reforms, see Stanley Lubman, Bird in a Cage: Legal Reform in China after Mao (Stanford: Stanford University Press, 1999).

92 In a related vein, the German Sinologist Harro Von Senger noted some years ago: "In the PRC statutory law thus does not serve the function of an autonomous force for shaping the social order, independent of the CCP Party norms. It serves rather as a vehicle for making casuistic elaborations to Party norms and their translation into guiding principles which are compulsory for all citizens of the PRC". Harro Von Senger, "Recent Developments in the Relations between State and Party Norms in the People's Republic of China", in Stuart R. Schram (ed.), The Scope of State Power in China (New York: St. Martin's Press, 1989), p. 207.

93 Su Shaozhi remarks ruefully that "Chinese society has long been characterized by state worship". See his "Problems of Democratic Reform in China", in Edward Friedman (ed.), The Politics of Democratization: Generalizing East Asian Experiences (Boulder: Westview Press, 1994), p. 223. Examples of "rules conscious" protests in the Maoist era can be found in Elizabeth J. Perry, "Shanghai's Strike Wave", and Elizabeth J. Perry and Li Xun, Protetarian Power.

94 Albert O. Hirschman, Exit, Voice and Loyalty: Responses to Decline in Firms, Organizations and States (Cambridge: Harvard University Press, 1970). 
Democracy Wall in 1979. In China, unlike Eastern Europe or the former Soviet Union, both leaders and ordinary citizens know how to put the genie of mass protest back into the bottle of state socialism.

One might well ask whether this is only a temporary situation, now that educated engineers rather than experienced revolutionaries occupy Zhongnanhai. ${ }^{95}$ Has the revolutionary tradition lost its intrinsic value for contemporary Chinese, rulers and ruled alike, much as Joseph Levenson argued was the fate of the Confucian tradition a century ago? ${ }^{96}$ Will today's Communist reformers find it as impossible to cling to their discredited traditions as the Qing self-strengtheners once did? Just as the abolition of the Confucian examinations was a clear acknowledgment of bureaucratic weakness and moral bankruptcy in 1905 , the CCP's resort to an open-door policy that welcomes even capitalists into Party is a clear acknowledgment of its own moribund condition.

It is entirely possible that the engineers responsible for running the train of Chinese Communism will soon discover that they cannot proceed full steam ahead along an outmoded set of rails. Advanced economic development may indeed demand new political arrangements that afford far greater autonomy to legal institutions and civil society. Without a willingness on the part of its leadership to risk the consequences of such a political transformation, the PRC could devolve into a run-of-the-mill authoritarianism that dispenses with both the ideological and the organizational features of its revolutionary past. Even if this "transition" to stable authoritarianism should occur (as some suggest it already has), ${ }^{97}$ we would still be well advised to cast a more discerning eye back upon the past quarter-century. Tarnished as the extraordinary, and quite unanticipated, accomplishments of the post-Mao polity may be, their explanation nevertheless presents a major challenge to the field of Chinese politics. That challenge, I would submit, cannot be fully met by comparisons with other countries (whether post-Communist, "classic" authoritarian or developmental), nor by recourse to general theories of regime transition and democratization..$^{98}$ For better and worse, China has yet to bid farewell to revolution.

95 On the changing of the élite guard, see Li Cheng, China's Leaders: The New Generation (Lanham: Rowman and Littlefield, 2001).

96 Joseph R. Levenson, Confucian China and Its Modern Fate: A Trilogy (Berkeley: University of California Press, 1968).

97 In addition to Andrew J. Nathan, "Authoritarian Resilience", see also Cheng Chen, "Institutional Legitimacy of an Authoritarian State: China in the Mirror of Eastern Europe", Problems of Post-Communism, Vol. 52, No. 4 (July/August 2005), pp. 3-13.

98 It may be significant, however, that all of the other remaining Communist regimes-Cuba, North Korea, Vietnam and Laos — share with China a legacy of nationalistic rural revolution. 
Copyright of China Journal is the property of Contemporary China Centre Research School of Pacific \& Asian Studies and its content may not be copied or emailed to multiple sites or posted to a listserv without the copyright holder's express written permission. However, users may print. download, or email articles for individual use. 